\title{
Development of an improved two-sphere integration technique for quantifying black carbon concentrations in the atmosphere and seasonal snow
}

\author{
Xin Wang ${ }^{1,2}$, Xueying Zhang ${ }^{3}$, and Wenjing $\mathbf{D i}^{1}$ \\ ${ }^{1}$ Key Laboratory for Semi-Arid Climate Change of the Ministry of Education, Lanzhou University, \\ Lanzhou 730000, Gansu, China \\ ${ }^{2}$ Institute of Surface-Earth System Science, Tianjin University, Tianjin 300072, China \\ ${ }^{3}$ Jilin Weather Modification Office, Changchun 132000, Jilin, China
}

Correspondence: Xin Wang (wxin@1zu.edu.cn)

Received: 7 August 2019 - Discussion started: 6 September 2019

Revised: 25 November 2019 - Accepted: 30 November 2019 - Published: 8 January 2020

\begin{abstract}
An improved two-sphere integration (TSI) technique has been developed to quantify black carbon (BC) concentrations in the atmosphere and seasonal snow. The major advantage of this system is that it combines two distinct integrated spheres to reduce the scattering effect due to light-absorbing particles and thus provides accurate determinations of total light absorption from BC collected on Nuclepore filters. The TSI technique can be calibrated using a series of 15 filter samples of standard fullerene soot. This technique quantifies the mass of $\mathrm{BC}$ by separating the spectrally resolved total light absorption into $\mathrm{BC}$ and non$\mathrm{BC}$ fractions. To assess the accuracy of the improved system, an empirical procedure for measuring BC concentrations with a two-step thermal-optical method is also applied. Laboratory results indicate that the $\mathrm{BC}$ concentrations determined using the TSI technique and theoretical calculations are well correlated $\left(R^{2}=0.99\right)$, whereas the thermal-optical method underestimates BC concentrations by $35 \%-45 \%$ compared to that measured by the TSI technique. Assessments of the two methods for atmospheric and snow samples revealed excellent agreement, with least-squares regression lines with slopes of $1.72\left(r^{2}=0.67\right)$ and $0.84\left(r^{2}=0.93\right)$, respectively. However, the TSI technique is more accurate in quantifications of $\mathrm{BC}$ concentrations in both the atmosphere and seasonal snow, with an overall lower uncertainty. Using the improved TSI technique, we find that light absorption at a wavelength of $550 \mathrm{~nm}$ due to BC plays a dominant role relative to non-BC light absorption in both the atmo-
\end{abstract}

sphere $(62.76 \%-91.84 \%$ of total light absorption) and seasonal snow (43.11\%-88.56\%) over northern China.

\section{Introduction}

Black carbon (BC) has long been recognized as the major light-absorbing particle (LAP) in both natural and anthropogenic emissions (Slater et al., 2002; Koch et al., 2009; Zhang et al., 2009; Pan et al., 2010; McMeeking et al., 2011; Pavese et al., 2012; Bond et al., 2013; IPCC, 2013). BC can impact the regional and global climate in several ways, including via the direct effects of scattering and absorbing visible solar radiation (Jacobson, 2001; Menon et al., 2002; Hansen et al., 2005; Ramanathan and Carmichael, 2008), the semi-direct effects of changing the temperature structure and relative humidity of the atmosphere by absorbing solar shortwave radiation (Ban-Weiss et al., 2012), and indirect effects on cloud formation and lifetime (Chuang et al., 2002; Baumgardner et al., 2004; Rosenfeld et al., 2008). Once deposited onto snow or ice surfaces, BC absorbs more solar radiation than pure snow or ice and reduces the snow albedo, thus accelerating snowmelt (Xu et al., 2009a; Flanner et al., 2012; Hadley and Kirchstetter, 2012; Carmagnola et al., 2013; Qian et al., 2014; Zhao et al., 2014).

Optically classified BC is also often referred to as elemental carbon (EC), which is typically thermally detected. The distinction between $\mathrm{BC}$ and $\mathrm{EC}$ has been debated since the 
1980s (Heintzenberg, 1989; Horvath, 1993a; Andreae and Gelencser, 2006; Moosmuller et al., 2009). Given that BC and EC are both soot particles with diameters of $<1 \mu \mathrm{m}$, these terms have often been used interchangeably (Chow et al., 2001, 2004; Ming et al., 2009; Thevenon et al., 2009; Lim et al., 2014). BC is generally regarded as an ideal lightabsorbing particle of carbon and is typically measured using optical attenuation methods (Clarke et al., 1967; Hansen et al., 1984; Ogren and Charlson, 1983; Grenfell et al., 2011). The term "EC" is often used interchangeably with "BC" when referring to optical absorption measurements (Clarke et al., 1967; Grenfell et al., 2011) and is only uniquely identified by thermal-optical methods (Xu et al., 2006; Cao et al., 2007; Jimenez et al., 2009). Poor agreement remains between measurements of BC and EC among available measurement techniques. The general techniques used to quantify the various fractions of $\mathrm{BC}$ mass concentrations are associated with the corresponding methods: thermal-optical methods, single-particle soot photometer (SP2) measurements, and filter-based optical techniques. Besides the above techniques, aerosol mass spectrometry, electron microscopy, and Raman spectroscopy are also useful and accurate methods to identify the various fractions of carbonaceous aerosols in the atmosphere (Ivleva et al., 2007; Spencer et al., 2007; Cross et al., 2010; Li et al., 2016; Petzold et al., 2013). Among these methods, the thermal-optical approach is regarded as the most effective and reliable for evaluating EC concentrations (Chylek et al., 1987; Cachier and Pertuisot, 1994; Jenk et al., 2006; Legrand et al., 2007; Hadley et al., 2010). However, the thermal-optical method can lead to large discrepancies in determining EC concentrations as a result of inference from positive artifacts caused by inadequately separated organics and mineral dust (Ballach et al., 2001; Wang et al., 2012). Further discrepancies are caused by the use of two main detection protocols (thermal-optical transmission, TOT; thermal-optical reflectance, TOR) to assess EC and $\mathrm{OC}$ concentrations based on their unique thermal properties. These protocols yield different OC and EC concentrations (Chow et al., 1993, 2001; Birch and Cary, 1996; Watson and Chow, 2002). The integrating sphere-integrating sandwich spectrophotometer (ISSW) method was developed by Grenfell et al. (2011) and has been used to analyze mass concentrations of BC in snow (Doherty et al., 2010, 2014; Wang et al., 2013). Doherty et al. (2010) noted that the total uncertainty in measuring $\mathrm{BC}$ in snow using the ISSW method is up to $40 \%$ relative to the gravimetric standards of $\mathrm{BC}$ (fullerene soot). The total uncertainty associated with the filter-based ISSW technique on BC concentration determination for ambient snow has previously been estimated as $40 \%$, which is the sum, in quadrature, of $11 \%$ for instrumental uncertainty, $15 \%$ for undercatch uncertainty (loss of insoluble light-absorbing impurities), $17 \%$ for BC mass absorption coefficient (MAC) uncertainty, and $30 \%$ for uncertainty in the absorption Ångström exponent (AAE) of non-BC material (Doherty et al., 2010; Grenfell et al., 2011; Schwarz et al.,

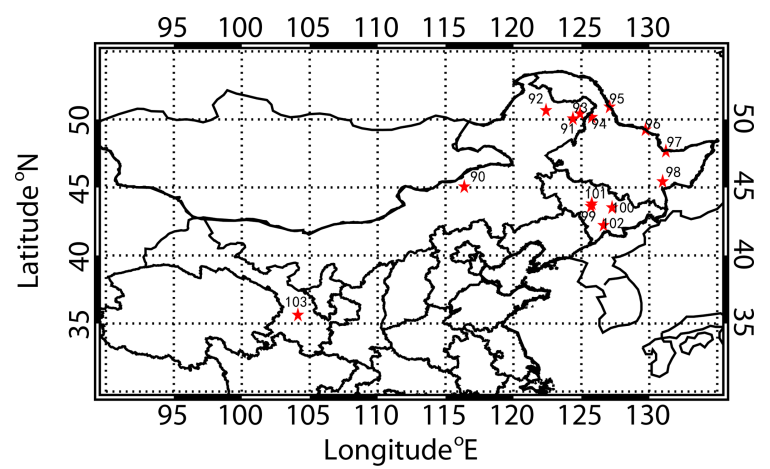

Figure 1. Sampling locations. Sites 90-102 are located in northeast China and were used for snow sample collection during JanuaryFebruary 2014. Snow sampling site 103 is located in Lanzhou in northwest China and was used for atmospheric sample collection during 5-25 August 2015. Sites are numbered according to Wang et al. (2013) and Ye et al. (2012).

2012). Finally, the SP2 technique is well suited to the quantification of low $\mathrm{BC}$ concentrations with a small particle radius $(<500 \mathrm{~nm})$. It is an optimized method for measuring BC concentrations and size distributions, and the substantially larger uncertainty of the SP2 instrument with respect to BC concentration measurements can exceed $60 \%$ in snow and ice cores and $30 \%$ for atmospheric sampling (Schwarz et al., 2012). They noted that the relative transmission efficiencies of polystyrene latex (PSL) sphere concentration standards in liquid to the SP2 after aerosolization are remarkably reduced to $20 \%$ due to the larger diameter of BC particles $(>500 \mathrm{~nm})$. Therefore, the larger diameter of BC $(>500 \mathrm{~nm})$ is hardly captured by SP2 instruments with a collision-type nebulizer. Moreover, the mixing status of BC in snow is more complicated than the standard fullerene soot in the laboratory and the typical BC in the atmosphere.

Although several field campaigns have collected atmospheric, snow, and ice core samples to measure BC and EC concentrations globally (Wolff and Cachier, 1998; von Schneidemesser et al., 2009; Doherty et al., 2010, 2014; Ming et al., 2010; Huang et al., 2011; Xu et al., 2012; Cong et al., 2015), biases remain in determinations of BC concentrations, as is evident from a comparison among the results obtained with the SP2, ISSW, and thermal-optical methods (Schwarz et al., 2012; Lim et al., 2014). As a result, it is difficult to assess the effects of $\mathrm{BC}$ and $\mathrm{EC}$ on recent climate change using different techniques, even in the same area.

Here we report the development of a new portable and accurate spectrophotometric method based on the two-sphere integration (TSI) technique that can be used to determine BC concentrations in both the atmosphere and seasonal snow. The improved TSI technique minimizes scattering effects related to $\mathrm{BC}$ and non-BC insoluble particles collected on $\mathrm{Nu}$ clepore filters and thus provides a simple and accurate means to assess $\mathrm{BC}$ concentrations in the atmosphere and seasonal 


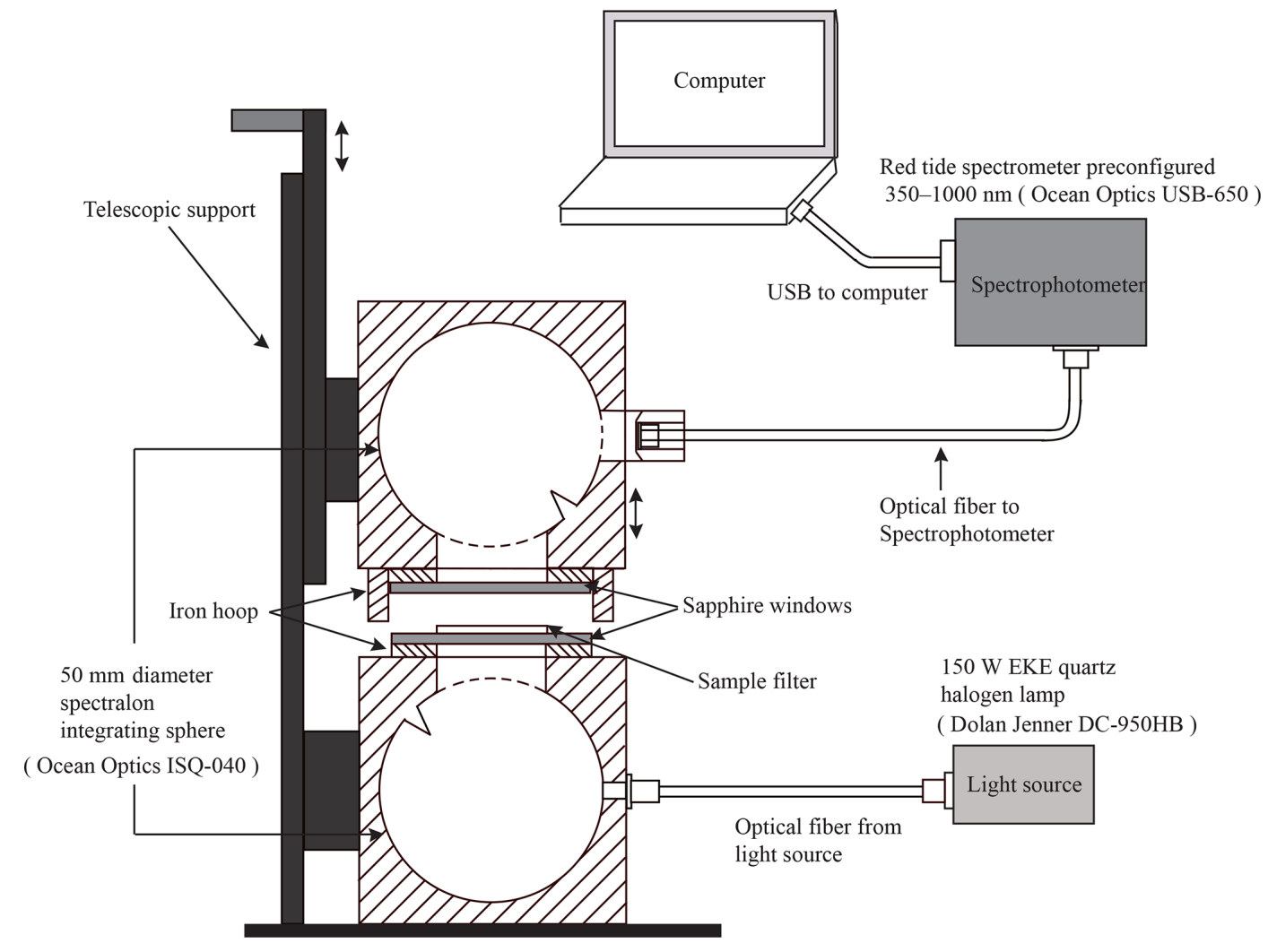

Figure 2. Schematic diagram of the improved two-sphere integrating spectrophotometer.

snow. To assess the accuracy of the new technique, a twostep thermal-optical method is applied to determine BC concentrations on individual quartz-fiber filters. Finally, we investigate the spatial distribution of $\mathrm{BC}$ concentrations and the relative light absorption of surface snow over northeast China. We also analyze the diurnal variations of $\mathrm{BC}$ in the atmosphere during day and night over Lanzhou in northwest China.

\section{Experimental procedures}

\subsection{Sampling sites and snow sample filtration}

During the study period, less snow fell in 2014 than in 2010, and no seasonal snow was present in the western part of Inner Mongolia. Therefore, we collected 94 snow samples at 14 sites in January and February of 2014 across north China following the sampling route of Huang et al. (2011). The sites are numbered in chronological order from 90 to 103, following previous snow surveys (Ye et al., 2012; Wang et al., 2013). Figure 1 shows the locations of the snow field campaigns across northern China. The sampling locations were selected to be at least $50 \mathrm{~km}$ from any settlement and $1 \mathrm{~km}$ from the nearest road. Snow samples were kept frozen before being filtered. We set up a temporary laboratory along the sampling route. Owing to $\mathrm{BC}$ in snow often being hydrophobic, long-time melting could cause more BC loss to the container walls instead of being collected on the filter (Ogren et al., 1983). In order to minimize the loss of insoluble LAPs (ILAPs), we quickly melted the snow samples in a microwave within a very short time. Therefore, the loss of insoluble LAPs is very limited and can be neglectable. At present, this method is a widely performed snow-melting procedure (Dothery et al., 2010, 2014; Wang et al., 2013). Subsequently, we simultaneously filtered the snow samples using quartz-fiber filters with $1 \mu \mathrm{m}$ pores and Nuclepore filters with $0.4 \mu \mathrm{m}$ pores. Then, we refiltered the snow samples for the quartz-fiber filters using Nuclepore filters with $0.4 \mu \mathrm{m}$ pores to account for the loss of BC mass in the $1 \mu \mathrm{m}$ pore quartz-fiber filters. Finally, we stored the original and refiltered snow samples in clean high-density polyethylene bottles in a freezer at $-30^{\circ} \mathrm{C}$ for subsequent analysis. For details of the sampling and filtration procedures, see Wang et al. (2013).

To evaluate the accuracy of the TSI technique in measuring BC concentrations, the atmospheric samples were continuously collected on Nuclepore and quartz-fiber filters with high-volume samplers during the periods 09:00 to 17:00 (daytime; local time) and 23:00 to 07:00 (nighttime) at site 103 in Lanzhou from 5 to 25 August 2015. The pumps were operated at a flow rate of $10 \mathrm{~L} \mathrm{~min}^{-1}$. In total, 40 atmo- 
spheric samples were collected during this experiment and used to assess the accuracy of the atmospheric BC concentration measurements of the improved TSI technique.

\subsection{Two-sphere integration technique}

Light transmission techniques are the most commonly used methods for determining light-absorbing impurities in aerosol filter samples of the atmosphere and snow-ice. Since the 1970s, a series of optical attenuation techniques have been developed for estimating BC concentrations using light transmission changes through filters based on Beer's law. An integrating sphere (IS) technique was first proposed for measuring BC by Fischer (1970). The integrating sphere was coated with diffusely reflecting white paint through a small hole, and the reduction in signal after measuring the sample filters represented the absorption of BC. Subsequently, a new integrating plate (IP) instrument was developed to measure scavenging BC on filters based on the IS technique, which uses a light-diffusing support to provide a nearly Lambertian light source for light transmission using $0.4 \mu \mathrm{m}$ Nuclepore filters (Clarke et al., 1967; Horvath, 1993b). However, the multiple scattering of solar radiation affects the accuracy of the IP technique (Clarke et al., 1967; Hitzenberger, 1993; Petzold et al., 1997; Bond et al., 1999). A new integrating sandwich configuration of the ISSW instrument was designed to measure the absorption of light-absorbing impurities based on the ISSW principle of Grenfell et al. (2011). The ISSW instrument can isolate the absorption properties of light-absorbing impurities deposited on polycarbonate $\mathrm{Nu}-$ clepore filters. By assuming the mass absorption efficiency and non-BC Ångström exponent at $550 \mathrm{~nm}$, this technique is currently capable of reliably measuring $\mathrm{BC}$ and non- $\mathrm{BC}$ light absorption (Wang et al., 2013; Dang and Hegg, 2014; Doherty et al., 2014). However, Schwarz et al. (2012) found that the total instrumental uncertainty associated with ISSW $\mathrm{BC}$ concentration determinations for ambient snow is $11 \%$, and this uncertainty is partially due to the scattering effects of insoluble impurities deposited on the filters (Doherty et al., 2010; Grenfell et al., 2011).

The improved TSI spectrophotometer developed in this study is small, lightweight, and portable, and it can accurately quantify $\mathrm{BC}$ concentrations using a technique based on the integrating sphere and integrating plate transmission techniques (Fig. 2). The major improvement of this spectrophotometer is that we replaced the integrating sandwich of the ISSW instrument developed by Grenfell et al. (2011) with a new integrating sphere. In addition, an iron hoop is applied to the top integrating sphere surrounding the sapphire windows to reduce light scattering due to insoluble particles on the filters. Therefore, the total relative light absorption due to all insoluble impurities on the filter can be estimated from the visible to near-infrared wavelengths. The total light attenuation can be calculated from the light transmitted by a snow or atmospheric sample, $S(\lambda)$, compared with that transmitted

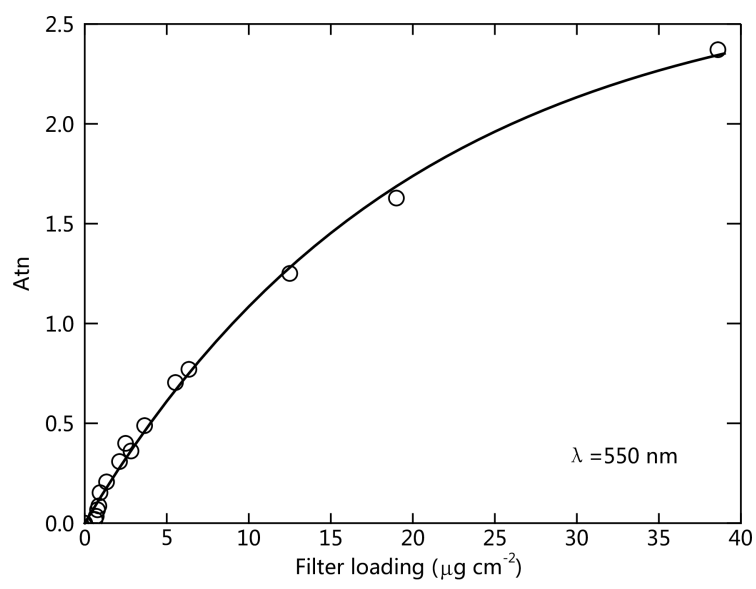

Figure 3. Calibration curve for standard fullerene soot at a wavelength of $550 \mathrm{~nm}$. The solid line is a best-fit curve for the filter measurements. $S_{0}$ and $S$ are the detected signals for the blank and sample filters, respectively, and $-\ln \left(S / S_{0}\right)$ is the relative attenuation.

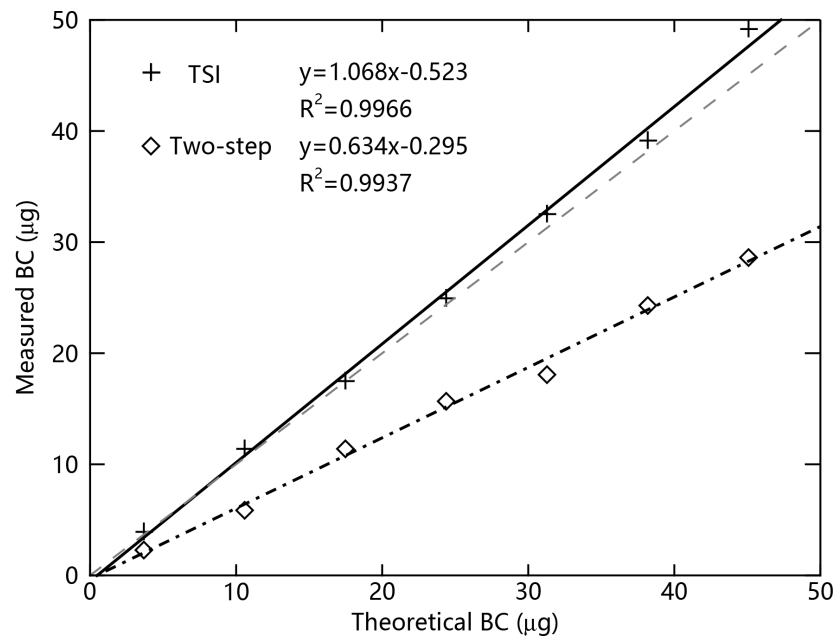

Figure 4. Comparison of the theoretical and measured BC mass determined by the TSI and two-step techniques in the laboratory. The solid and dot-dashed lines represent best-fit lines for the TSI and two-step techniques, respectively. The dashed line is a $1: 1$ line.

by a blank filter, $S_{0}(\lambda)$. Then, the relative attenuation (Atn) through the filter can be expressed as follows:

$\operatorname{Atn}=\ln \left[S(\lambda) / S_{0}(\lambda)\right]$.

The total absorption Ångström exponent $\AA_{\text {tot }}\left(\lambda_{0}\right)$ of all the ILAPs on the filters can be calculated from the following formula:

$\AA_{\text {tot }}\left(\lambda_{0}\right)=-\frac{\ln \left[\tau_{\text {tot }}\left(\lambda_{1}\right) / \tau_{\text {tot }}\left(\lambda_{2}\right)\right]}{\ln \left(\lambda_{1} / \lambda_{2}\right)}$.

$\AA_{\text {non-BC }}$ is calculated as a linear combination of the contributions to light absorption made by OC and Fe:

$\AA_{\text {non- } \mathrm{BC}}=\AA_{\mathrm{OC}} \times f_{\mathrm{OC}}+\AA_{\mathrm{Fe}} \times f_{\mathrm{Fe}}$. 
Table 1. Series of 15 standard filters loaded with fullerene soot and a comparison of BC concentrations between theoretical calculations and the TSI and two-step thermal-optical methods in the laboratory.

\begin{tabular}{lrrr|rrrr}
\hline Filter & $\begin{array}{r}\text { Standard BC concentration } \\
\left(\mu \mathrm{g} \mathrm{cm}^{-2}\right)\end{array}$ & Filter & $\begin{array}{r}\text { Standard BC concentration } \\
\left(\mu \mathrm{g} \mathrm{cm}^{-2}\right)\end{array}$ & $\begin{array}{r}\text { Filter } \\
\text { Calculated BC } \\
(\mu \mathrm{g})\end{array}$ & $\begin{array}{r}\text { TSI BC } \\
(\mu \mathrm{g})\end{array}$ & $\begin{array}{r}\text { Two-step BC } \\
(\mu \mathrm{g})\end{array}$ \\
\hline 1 & 0.63 & 9 & 2.82 & 1 & 3.68 & 3.92 & 2.28 \\
2 & 0.70 & 10 & 3.65 & 2 & 10.58 & 11.39 & 5.86 \\
3 & 0.78 & 11 & 5.53 & 3 & 17.48 & 17.49 & 11.39 \\
4 & 0.86 & 12 & 6.35 & 4 & 24.38 & 24.94 & 15.67 \\
5 & 0.93 & 13 & 12.5 & 5 & 31.28 & 32.52 & 18.07 \\
6 & 1.33 & 14 & 19.00 & 6 & 38.18 & 39.14 & 24.29 \\
7 & 2.12 & 15 & 38.6 & 7 & 45.08 & 49.18 & 28.61 \\
8 & 2.49 & - & - & - & - & - & \\
\hline
\end{tabular}

The total absorption Ångström exponent of all ILAPs on a filter $\left(\AA_{\text {tot }}\right)$ can be described as a linear combination of $\AA_{B C}$

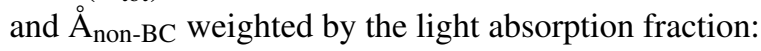

$\AA_{\text {tot }}\left(\lambda_{0}\right)=\AA_{\mathrm{BC}} \times f_{\mathrm{BC}}\left(\lambda_{0}\right)+\AA_{\text {non-BC }} \times f_{\text {non-BC }}\left(\lambda_{0}\right)$.

Using the mass absorption efficiency and absorption Ångström exponents for BC, OC, and Fe described by Wang et al. (2013), we can further estimate the following parameters: equivalent $\mathrm{BC}\left(C_{\mathrm{BC}}^{\text {equiv }}\right)$, maximum $\mathrm{BC}\left(C_{\mathrm{BC}}^{\max }\right)$, estimated $\mathrm{BC}\left(C_{\mathrm{BC}}^{\text {est }}\right)$, fraction of light absorption by non-BC ILAPs (insoluble light-absorbing particles) $\left(f_{\text {non-BC }}^{\text {est }}\right)$, absorption Ångström exponent of non-BC ILAPs $\left(A_{\text {non-BC }}\right)$, and total absorption Ångström exponent $\left(\AA_{\text {tot }}\right)$. These parameters are defined as follows.

1. $C_{\mathrm{BC}}^{\text {equiv }}\left(\mathrm{ng} \mathrm{g}^{-1}\right)$ : equivalent $B C$ is the amount of $\mathrm{BC}$ that would be needed to produce the total light absorption by all insoluble particles in snow for wavelengths of 300$750 \mathrm{~nm}$.

2. $C_{\mathrm{BC}}^{\max }\left(\mathrm{ng} \mathrm{g}^{-1}\right)$ : maximum $B C$ is the maximum possible $\mathrm{BC}$ mixing ratio in snow, assuming that all light absorption is due to $\mathrm{BC}$ at wavelengths of $650-700 \mathrm{~nm}$.

3. $C_{\mathrm{BC}}^{\mathrm{est}}\left(\mathrm{ng} \mathrm{g}^{-1}\right)$ : estimated $B C$ is the estimated true mass of $B C$ in snow derived by separating the spectrally resolved total light absorption and non-BC fractions.

4. $f_{\text {non-BC }}^{\text {est }}(\%)$ : the fraction of light absorption by non-BC light-absorbing particles is the integrated absorption due to non-BC light-absorbing particles. This value is weighted by the downwelling solar flux at wavelengths of $300-750 \mathrm{~nm}$.

5. $\AA_{\text {non-BC: }}$ the non-BC absorption Angström exponent is derived from the light absorption by non-BC components for wavelengths of $450-600 \mathrm{~nm}$.

6. $\AA_{\text {tot }}$ : the absorption Angström exponent is calculated for all insoluble particles deposited on the filter between 450 and $600 \mathrm{~nm}$.
Furthermore, combined with the mass loading of Fe determined by chemical analysis (Wang et al., 2013), the mass loading of $\mathrm{OC}\left(L_{\mathrm{OC}}\right)$ was also estimated assuming that the MAC for OC is $0.3 \mathrm{~m}^{2} \mathrm{~g}^{-1}$ at the wavelength of $550 \mathrm{~nm}$ using the following equation:

$$
\begin{aligned}
\tau_{\text {tot }}(\lambda) & -\operatorname{MAC}_{\mathrm{BC}}(\lambda) \times L_{\mathrm{BC}}^{\mathrm{est}}-\mathrm{MAC}_{\mathrm{Fe}} \times L_{\mathrm{Fe}} \\
& =\operatorname{MAC}_{\mathrm{OC}} \times L_{\mathrm{OC}} .
\end{aligned}
$$

All relevant equations and associated derivations are described by Grenfell et al. (2011) and Doherty et al. (2010, 2014). Note that the calculation of non-BC light absorption due to insoluble impurities assumes that the iron in snow is predominantly from mineral dust (Wang et al., 2013).

\subsection{Calibration of the TSI spectrophotometer}

In this study, a series of 15 Nuclepore filters with a pore size of $0.2 \mu \mathrm{m}$ (lot no. 7012284, $25 \mathrm{~mm}$, Whatman) loaded with fullerene soot (stock no. 40971, lot no. L20W054, Alfa Aesar, Ward Hill, MA, USA) is used to calibrate the spectrophotometer over the range $0.63-38.6 \mu \mathrm{g}$, which typically covers $>75 \%$ of ambient accumulation-mode mass (left panel in Table 1; Schwarz et al., 2012). Fullerene soot is commonly used for calibrating the light transmission and thermal-optical techniques for measuring $\mathrm{BC}$ concentrations (Baumgardner et al., 2012). Standard fullerene soot particles are fractallike aggregates of spherical primary particles with a diameter of $\sim 50 \mathrm{~nm}$, with a mean density of $1.05 \mathrm{~g} \mathrm{~cm}^{-3}$ (Moteki et al., 2009). Multiple filters with various loadings are required, as the system response deviates from Beer's law exponential behavior; related equations can be found in Grenfell et al. (2011). Note that uncertainties in mass absorption efficiencies, which range from 2 to $25 \mathrm{~m}^{2} \mathrm{~g}^{-1}$, can lead to uncertainty in this technique. Here, we use a mass absorption efficiency of $6.22 \mathrm{~m}^{2} \mathrm{~g}^{-1}$ at $525 \mathrm{~nm}$, which is consistent with Doherty et al. (2010) and Grenfell et al. (2011). Figure 3 shows the best-fit curve (solid line) of the loading of the filters at $550 \mathrm{~nm}$. When the filter loading was $0-40 \mu \mathrm{g} \mathrm{cm}^{-2}$, all measured results were close to the best-fit curve, indicat- 


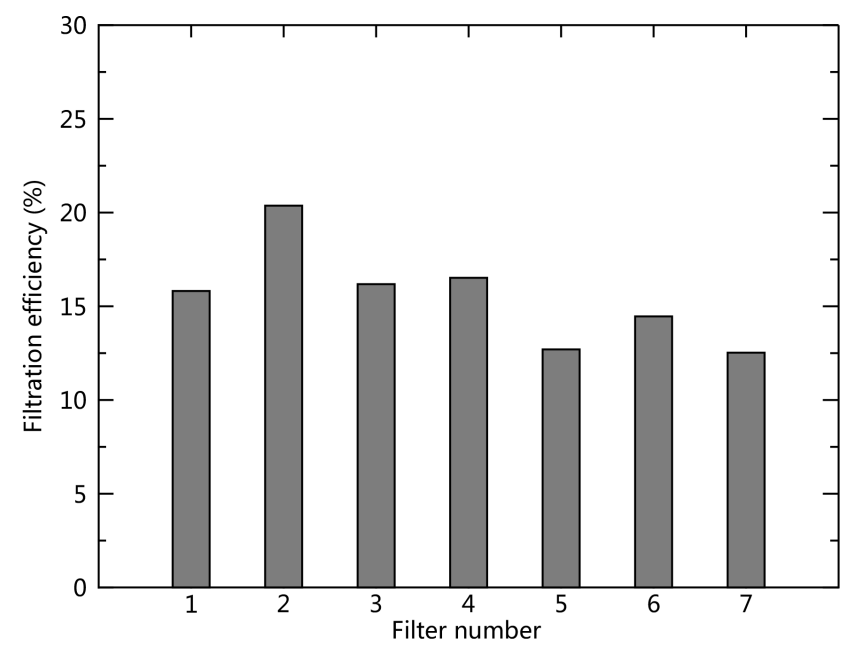

Figure 5. Mass loss of standard fullerene soot on $1.0 \mu \mathrm{m}$ quartzfiber filters determined by refiltration using $0.4 \mu \mathrm{m}$ Nuclepore filters.

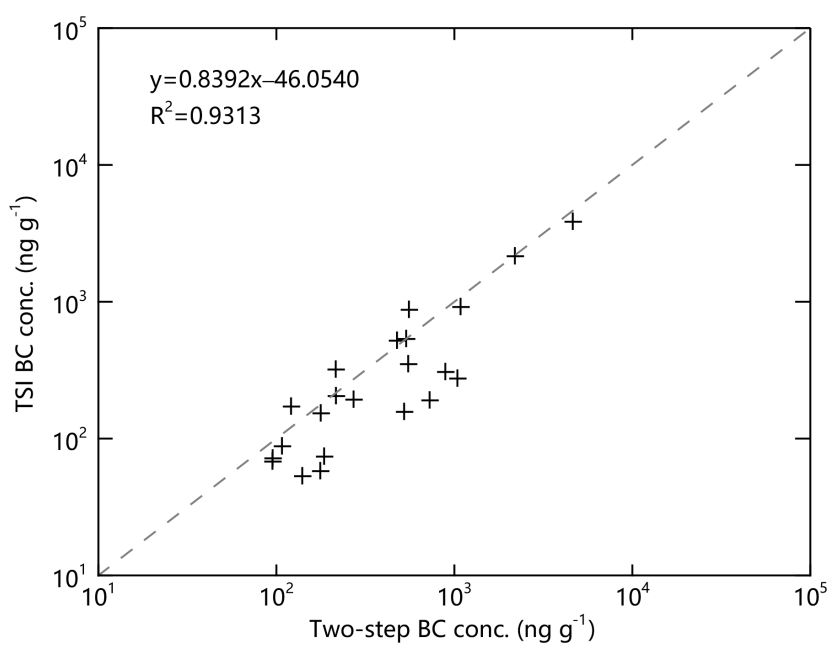

Figure 6. Comparison of BC concentrations in snow samples over northeast China during January-February 2014 determined by the TSI and two-step thermal optical methods. A $1: 1$ line (dashed) is shown.

ing that the TSI spectrophotometer is stable and accurate in terms of BC mass measurements.

\subsection{Thermal-optical measurements of EC concentration}

There are several types of thermal-optical methods that can be used to quantify EC and OC concentrations, including two-step temperatures in oxidizing and non-oxidizing atmospheres (Cachier et al., 1989; Xu et al., 2006, 2009b), thermal-optical reflectance (Chow et al., 1993, 2001; Chen et al., 2004), and thermal-optical transmittance (Sharma et al., 2002; Yang and Yu, 2002; Chow et al., 2004). Using an optimized two-step method, Cachier et al. (1989) first confirmed that soot carbon not only comprises EC, but is also mixed with highly condensed organic material. An optimized twostep thermal-optical system has been developed to detect EC and OC concentrations in ice cores (Xu et al., 2006). Here, we use the optimized two-step method based on the thermaloptical technique to measure EC concentrations. In this experiment, quartz-fiber filters were first preheated in a muffle furnace at $350^{\circ} \mathrm{C}$ to remove organic carbon prior to sampling. All filters were punched to yield appropriately sized samples for analysis. Snow samples were analyzed for EC and $\mathrm{OC}$ concentrations using a thermal-optical carbon analyzer (Desert Research Institute, model 2001A), following the thermal-optical reflectance (TOR) protocol of the Interagency Monitoring of Protected Visual Environments (IMPROVE_A). We developed a new method, referred to as the two-step method, to measure the concentrations of BC collected by the quartz-fiber filters. The two-step method is an updated measurement procedure that first extracts an $\mathrm{OC}$ fraction below $550^{\circ} \mathrm{C}$ in a $\mathrm{He}$ atmosphere. The volatilized OC is oxidized to $\mathrm{CO}_{2}$, reduced to $\mathrm{CH}_{4}$, and detected by a flame ionization system. Next, two EC fractions (EC1 and EC2) are extracted above $550^{\circ} \mathrm{C}$ in an atmosphere of $2 \%$ $\mathrm{O}_{2}$ and $98 \% \mathrm{He}$. Detailed procedures can be found in $\mathrm{Xu}$ et al. (2006) and Chow et al. (2004). The analytical uncertainty of this method is $15 \%$ for BC and $16 \%$ for OC measured via four parallel ice samples cut lengthways in an ice core with high dust loading (Xu et al., 2009a).

\section{Results}

\subsection{Comparison with theoretical calculations}

To further assess the accuracy of the TSI system, we use standard fullerene soot and quantify BC concentrations using theoretical calculations for comparison with $\mathrm{BC}$ values measured by a laboratory-based TSI spectrophotometer. To ensure the stability and accuracy of the improved TSI spectrophotometer, two individual sets of standard BC filters were used: $0.4 \mu \mathrm{m}$ Nuclepore and $1 \mu \mathrm{m}$ quartz-fiber filters. All filters were preheated in a muffle furnace at $350^{\circ} \mathrm{C}$ to remove organic carbon prior to sampling. A measured amount of $\mathrm{BC}$ was mixed into a known volume of ultrapure water. The mixture was then agitated by ultrasound for $\sim 10 \mathrm{~min}$, and the same volumes of liquid were then filtered through the two types of filters. Using the calculated BC mass, seven filters with gradually increasing $\mathrm{BC}$ concentrations were obtained for both the $0.4 \mu \mathrm{m}$ Nuclepore and $1 \mu \mathrm{m}$ quartz-fiber filters. Next, all the filters were placed in a dryer for $24 \mathrm{~h}$ and then measured using the TSI spectrophotometer. Using the $\mathrm{BC}$ mass and the volume of the ultrapure water used for filtration, we can estimate the theoretical BC concentration for each filter. The mass for each filter is listed in Table 1 (right panel). 


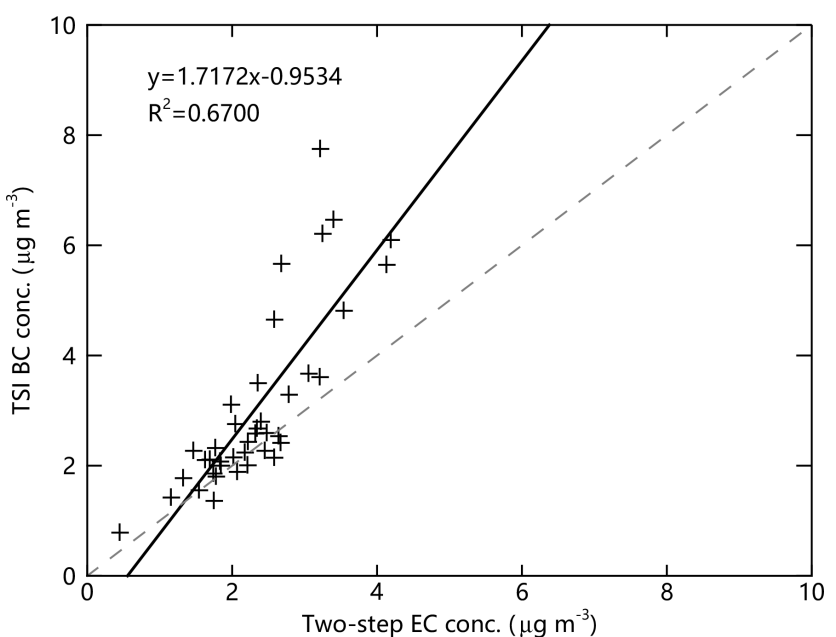

Figure 7. As for Fig. 6, but for atmospheric samples collected at Lanzhou in northwest China during 5-25 August 2015. A $1: 1$ line (dashed) and a linear regression fit passing through the origin (solid curve) are also shown.

Assuming a mass absorption cross section (MAC) of BC of $6.22 \mathrm{~m}^{2} \mathrm{~g}^{-1}$ at $525 \mathrm{~nm}$, the BC concentrations measured using the TSI spectrophotometer were in good agreement with the theoretical $\mathrm{BC}$ values, with a slope of 1.07 (Fig. 4). The BC mass loaded on the Nuclepore filters was approximately equal to that measured by the improved TSI spectrometer, which indicates that the TSI system developed here can accurately measure BC concentrations with the assumed mass absorption efficiency. In contrast, the standard BC mass on the quartz-fiber filters was underestimated by $35 \%-45 \%$ using the two-step thermal-optical technique compared with the theoretical value. During the filtration process, we found that the time required to filter liquid snow samples on the $0.4 \mu \mathrm{m}$ Nuclepore filters was much longer than was the case for the $1 \mu \mathrm{m}$ quartz-fiber filters. Therefore, we first filtered the melted snow samples on the quartz-fiber filters and then refiltered the snow samples using the $0.4 \mu \mathrm{m}$ Nuclepore filters. Using this process, $\mathrm{BC}$ mass losses can be obtained using the TSI technique, assuming that optical $\mathrm{BC}$ is equivalent to thermal EC.

As shown in Fig. 5, the fraction of BC mass collected during the second filtration $(0.4 \mu \mathrm{m}$ filter) ranges from $12 \%$ to $21 \%$ of the total collected mass (filter directly with $0.4 \mu \mathrm{m}$ filters), as might be expected for the small particles of standard fullerene soot $(<50 \mathrm{~nm})$. This under-sampled fraction decreases with increasing $\mathrm{BC}$ mass on the filters, possibly owing to blocking of the filter pores. As a result, the undersampled fraction of the thermal-optical method was larger than that of the TSI technique, leading to a lower filtration efficiency. Note that these sampling efficiencies are strongly related to the $\mathrm{BC}$ size distribution. Therefore, the improved TSI technique developed here is more stable and accurate for measuring pure $\mathrm{BC}$ masses, and the data obtained us-
Table 2. Statistics of BC and EC concentrations measured using the TSI and two-step thermal-optical methods for snow samples during the experiments over northern China.

\begin{tabular}{|c|c|c|c|}
\hline \multirow[t]{2}{*}{ Site } & \multirow[t]{2}{*}{ Filter } & \multirow{2}{*}{$\frac{\text { TSI BC }}{n g g^{-1}}$} & \multirow{2}{*}{$\begin{array}{r}\text { Two-step EC } \\
n g^{-1}\end{array}$} \\
\hline & & & \\
\hline 90 & Q-351L & 349.95 & 550.19 \\
\hline \multirow[t]{2}{*}{91} & Q-352L & 171.46 & 120.87 \\
\hline & Q-352R & 152.94 & 177.48 \\
\hline \multirow[t]{2}{*}{92} & Q-354L & 53.10 & 139.78 \\
\hline & Q-354R & 57.82 & 176.41 \\
\hline \multirow[t]{2}{*}{93} & Q-356L & 71.71 & 95.27 \\
\hline & Q-356R & 73.85 & 185.45 \\
\hline 94 & Q-358L & 274.62 & 1040.20 \\
\hline \multirow[t]{2}{*}{95} & Q-359L & 87.84 & 107.51 \\
\hline & Q-359R & 67.92 & 95.01 \\
\hline \multirow[t]{2}{*}{96} & Q-363L & 319.71 & 215.42 \\
\hline & Q-363R & 192.60 & 271.42 \\
\hline \multirow[t]{2}{*}{97} & Q-366L & 204.47 & 216.04 \\
\hline & Q-366R & 306.75 & 889.54 \\
\hline \multirow[t]{2}{*}{98} & Q-369L & 1605.95 & 130.36 \\
\hline & Q-369R & 1321.69 & 6004.33 \\
\hline \multirow[t]{2}{*}{99} & Q-376L & 873.58 & 555.39 \\
\hline & Q-376R & 534.70 & 536.11 \\
\hline 100 & Q-380R & 519.47 & 476.14 \\
\hline 101 & Q-384R & 3843.15 & 4626.72 \\
\hline \multirow[t]{2}{*}{102} & Q-388L & 915.59 & 1083.24 \\
\hline & Q-388R & 2151.18 & 2187.90 \\
\hline \multirow[t]{2}{*}{103} & Q-397L & 156.76 & 522.07 \\
\hline & Q-397R & 190.24 & 726.08 \\
\hline
\end{tabular}

ing this method can be used as the standard BC mass. After correcting for systematic biases, the results of both methods were closer to the theoretical BC calculations. Note, however, that the size distribution of the laboratory BC standard was much smaller than those of the atmospheric and seasonal snow samples (Schwarz et al., 2012). Therefore, underestimates caused by the filtration efficiency for ambient $\mathrm{BC}$ should be lower than that for the standard BC.

\subsection{Comparison of $\mathrm{BC}$ concentrations in seasonal snow and the atmosphere}

Recent studies have indicated that mineral dust can affect the accurate detection of $\mathrm{BC}$ concentrations using the ISSW and thermal-optical methods (Wang et al., 2012; Zhou et al., 2017). To eliminate the large uncertainty and bias due to dust particles, we only used snow samples collected in industrial 
Table 3. Statistics of BC and EC concentrations in atmospheric samples measured using the TSI and two-step thermal-optical methods.

\begin{tabular}{|c|c|c|c|c|c|}
\hline \multirow[b]{2}{*}{ Date } & \multicolumn{2}{|c|}{ Day } & \multirow[b]{2}{*}{ Date } & \multicolumn{2}{|c|}{ Night } \\
\hline & $\begin{array}{l}\text { TSI BC } \\
\mu \mathrm{g} \mathrm{m}^{-3}\end{array}$ & $\begin{array}{r}\text { Two-step EC } \\
\mu \mathrm{g} \mathrm{m}^{-3}\end{array}$ & & $\begin{array}{l}\text { TSI BC } \\
\mu \mathrm{g} \mathrm{m}^{-3}\end{array}$ & $\begin{array}{r}\text { Two-step EC } \\
\mu \mathrm{g} \mathrm{m}^{-3}\end{array}$ \\
\hline 2015.8 .6 & 2.41 & 2.67 & $2015.8 .5-8.6$ & 3.67 & 3.05 \\
\hline 2015.8 .7 & 1.36 & 1.75 & 2015.8.6-8.7 & 2.00 & 1.84 \\
\hline 2015.8 .8 & 1.89 & 2.07 & 2015.8.7-8.8 & 1.55 & 1.54 \\
\hline 2015.8 .9 & 2.01 & 2.21 & $2015.8 .8-8.9$ & 1.77 & 1.32 \\
\hline 2015.8 .10 & 2.24 & 2.17 & 2015.8.9-8.10 & 2.07 & 1.83 \\
\hline 2015.8 .11 & 2.80 & 2.40 & $2015.8 .10-8.11$ & 4.81 & 3.54 \\
\hline 2015.8 .12 & 2.11 & 1.69 & $2015.8 .11-8.12$ & 3.11 & 1.98 \\
\hline 2015.8 .13 & 0.78 & 0.45 & $2015.8 .13-8.14$ & 2.27 & 1.46 \\
\hline 2015.8 .14 & 1.80 & 1.78 & $2015.8 .14-8.15$ & 6.21 & 3.25 \\
\hline 2015.8 .15 & 2.58 & 2.32 & $2015.8 .15-8.16$ & 2.32 & 1.77 \\
\hline 2015.8 .16 & 3.61 & 3.21 & 2015.8.16-8.17 & 2.10 & 1.63 \\
\hline 2015.8 .17 & 2.76 & 2.04 & $2015.8 .17-8.18$ & 2.43 & 2.22 \\
\hline 2015.8 .18 & 1.42 & 1.15 & 2015.8.18-8.19 & 5.66 & 2.68 \\
\hline 2015.8.19 & 1.86 & 1.74 & 2015.8.19-8.20 & 7.75 & 3.21 \\
\hline 2015.8 .20 & 2.54 & 2.64 & $2015.8 .20-8.21$ & 2.59 & 2.48 \\
\hline 2015.8 .21 & 2.14 & 2.58 & $2015.8 .21-8.22$ & 6.46 & 3.40 \\
\hline 2015.8 .22 & 3.29 & 2.78 & $2015.8 .22-8.23$ & 3.50 & 2.35 \\
\hline 2015.8 .23 & 2.27 & 2.45 & $2015.8 .23-8.24$ & 4.65 & 2.58 \\
\hline 2015.8 .24 & 2.15 & 2.02 & $2015.8 .24-8.25$ & 5.65 & 4.13 \\
\hline 2015.8 .25 & 2.67 & 2.34 & $2015.8 .25-8.26$ & 6.10 & 4.19 \\
\hline
\end{tabular}

areas over northeastern China, where the light absorption was dominated by fine-mode ILAPs (e.g., BC and OC; Wang et al., 2013). Hence, most of the snow samples did not contain very large coarse-mode particles, such as mineral and local soil dust.

During the snow field campaign, two series of snow samples were filtered through the Nuclepore and quartz-fiber filters and measured using the TSI and two-step thermaloptical methods (Fig. 6). Result shows that most of the BC values measured by the TSI and two-step thermal-optical methods are close to the $1: 1$ line in a comparison plot and are generally in good agreement (slope of $1.11, R^{2}=0.93$, $n=22$ ). However, some BC values in seasonal snow measured by the two-step thermal-optical method are much larger than those measured by the TSI technique. Consequently, for each sample the mean ratio of $\mathrm{BC}$ concentrations measured by the two-step method and the TSI spectrophotometer varies from 0.64 to 3.97 , with an overall mean of 1.57. This discrepancy arises from two factors. First, Wang et al. (2017) found that snow grain sizes varied considerably (from 0.07 to $1.3 \mathrm{~mm}$ ) during this snow field campaign. This range is much larger than that recorded in previous studies, owing to snow melting by solar radiation and ILAPs (Hadley and Kirchstetter, 2012; Painter et al., 2013; Yasunari et al., 2013; Pedersen et al., 2015). These results agree well with those of Schwarz et al. (2012), who found that the sizes of $\mathrm{BC}$ particles in snow are much larger than those in typical ambient air. Therefore, the sampling efficiency of the quartz- fiber filters could have been significantly higher than expected. The other factor is that the insoluble light-absorbing impurities in seasonal snow over northeast China contained not only BC, but also insoluble organic carbon. This result is consistent with a previous study by Chow et al. (2004), who reported that the charring observed when employing the two-step thermal-optical method at higher temperatures $\left(>550^{\circ} \mathrm{C}\right)$ was incomplete and that certain organic compounds are not completely pyrolyzed below $550{ }^{\circ} \mathrm{C}$. Therefore, incomplete charring of absorbed organic compounds by the two-step processes may lead to incompletely pyrolyzed $\mathrm{OC}$ on the filters, artificially contributing to the $\mathrm{BC}$ concentration. This may explain why the $\mathrm{BC}$ concentration measured using the thermal-optical method was higher than that measured using the TSI spectrophotometer.

A comparison of $\mathrm{BC}$ concentrations in the atmosphere measured by the ISSW and thermal-optical methods reveals that they are vastly different than that for the snow samples (Fig. 7). Results are in excellent agreement for BC concentrations of $<3 \mu \mathrm{g} \mathrm{m}^{-3}$. However, biases increased gradually with increasing $\mathrm{BC}$ concentrations, leading to twostep-to-TSI ratios as low as 0.5. The BC concentrations of $>3 \mu \mathrm{g} \mathrm{m}{ }^{-3}$ obtained using the two-step thermal-optical method are much lower than those measured using the improved TSI technique, possibly due to the small particle sizes in the atmosphere, which lead to a lower filtration efficiency. Overall, we conclude that the improved TSI method is more stable and suitable for measuring BC concentrations in both 


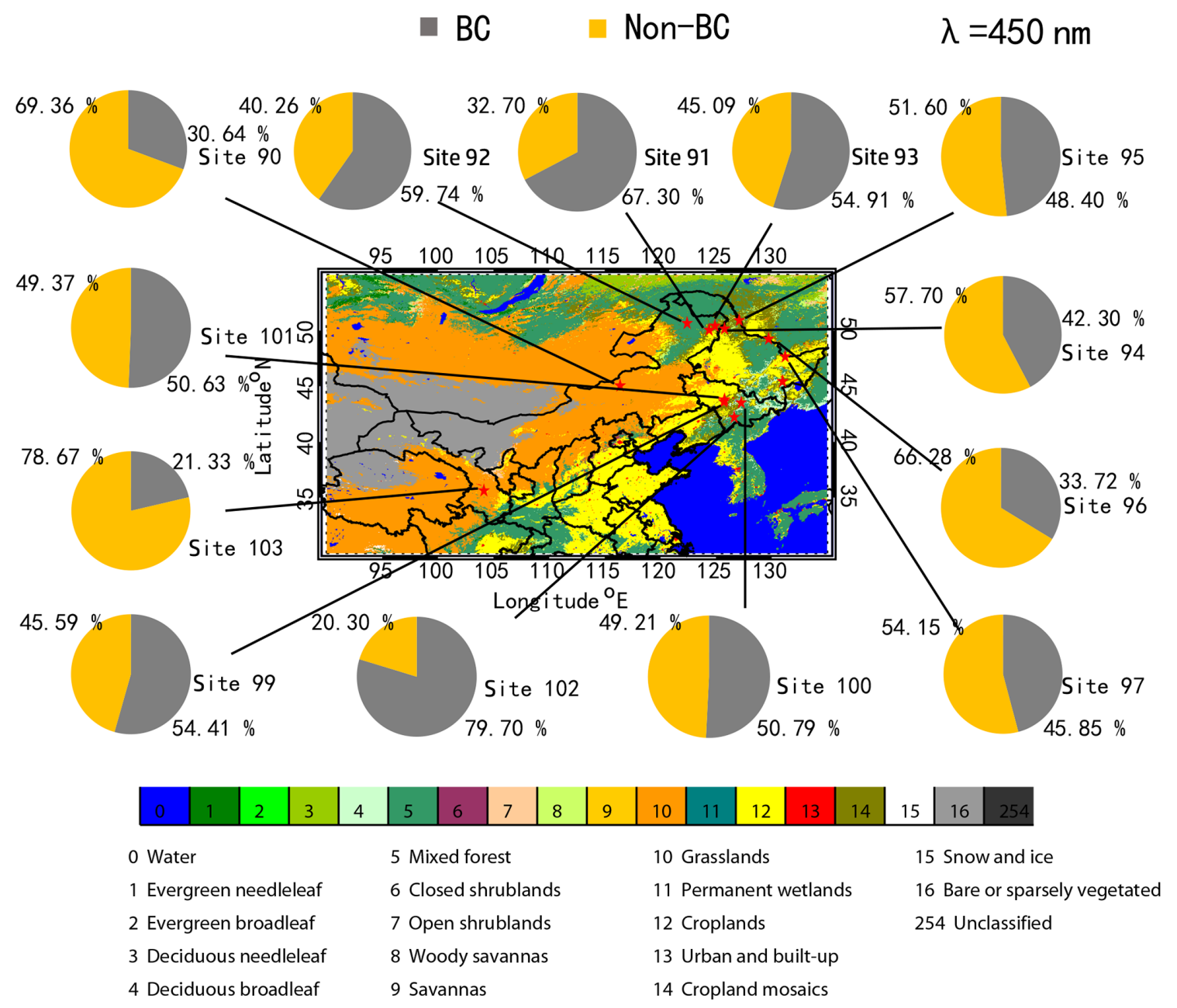

Figure 8. Spatial distributions of light absorption at $550 \mathrm{~nm}$ due to $\mathrm{BC}$ and non-BC fractions in surface snow across northern China during January-February 2014.

the atmosphere and snow samples compared with the twostep thermal-optical method.

\subsection{Spatial distribution of $\mathrm{BC}$ and non-BC light absorption measured by the TSI spectrophotometer}

The above results show that the improved TSI method measures BC concentrations in the atmosphere and snow-ice with higher accuracy than two-step thermal optical methods. In this section we investigate the spatial distribution of $\mathrm{BC}$ concentrations and their relative light absorption due to $\mathrm{BC}$ and non-BC snow impurities in seasonal snow over northeast China during January-February 2014. All BC mass concentrations in surface snow measured by the TSI and thermaloptical methods during the snow field campaigns are listed in Table 2. There was less snowfall in January 2014 than in 2010, and seasonal snow did not cover all of central Inner Mongolia during this time. Thus, we only collected snow samples at site 90 . Given that this region is windy, the surface snow collected included drifted and aged snow. The sur- face $\mathrm{BC}$ concentration was $350 \mathrm{ng} \mathrm{g}^{-1}$ in the central Inner Mongolia region. The lowest $\mathrm{BC}$ concentrations in surface snow, 55 and $28 \mathrm{ng} \mathrm{g}^{-1}$, were found on the border of northeast China (sites 91-97). We note that there were considerable variations in $\mathrm{BC}$ concentrations in these regions. The median $\mathrm{BC}$ concentration was $1100 \mathrm{ng} \mathrm{g}^{-1}$ with a range of $520-3900 \mathrm{ng} \mathrm{g}^{-1}$ for surface snow in northeast industrial regions. On 10 February 2014, fresh snow samples were collected in Lanzhou at a mean snow depth of 6-8 cm. The mean $\mathrm{BC}$ concentration in these fresh snow samples from Lanzhou was $\sim 170 \mathrm{ng} \mathrm{g}^{-1}$.

The relative light absorption due to $\mathrm{BC}$ and non- $\mathrm{BC}$ fractions in seasonal snow measured using the improved TSI technique across northern China is shown in Fig. 8. A similar pattern for the light absorption of $\mathrm{BC}(\sim 70 \%)$ and non-BC $(\sim 30 \%)$ from insoluble light-absorbing impurities in surface snow indicates a similar pollution emission source over northeast China. However, the light absorption due to BC in seasonal snow plays a dominant role $(43.11 \%-88.56 \%$, 

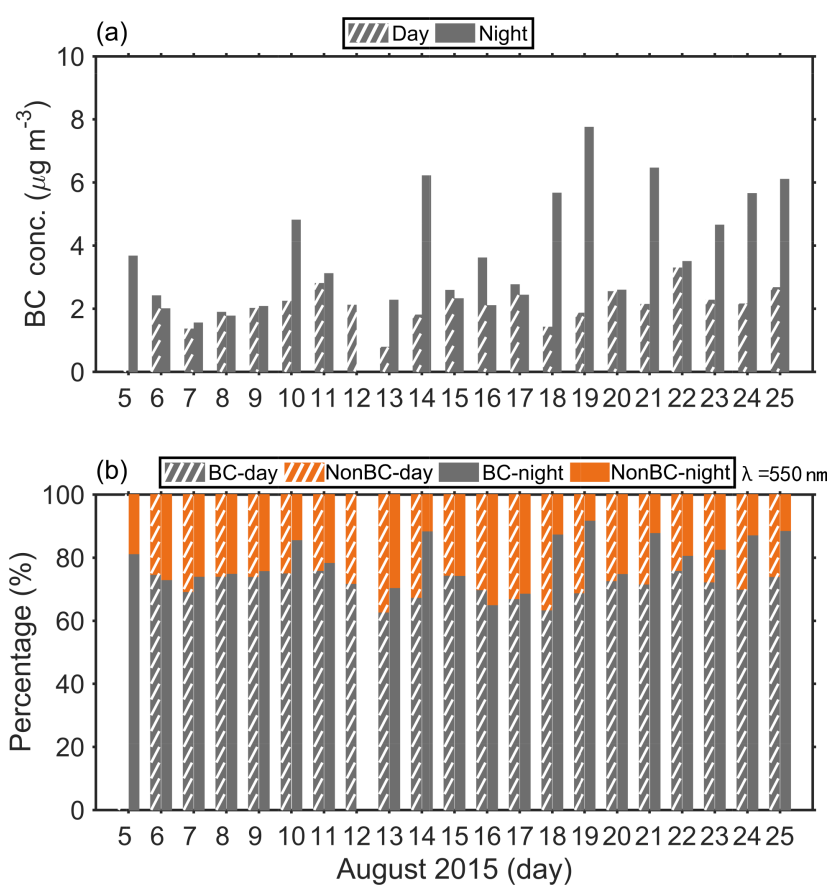

Figure 9. Variations in $8 \mathrm{~h}$ (a) BC concentration and (b) BC and non-BC light absorption measured by the TSI spectrophotometer at 550 nm at Lanzhou during 5-25 August 2015 (day: 09:00 to 17:00; night: 23:00 to 07:00).

with a mean of $73.10 \%)$. The largest BC light absorption was at site 102. This site is located in the central part of Jilin province, which is polluted by heavy industrial activity. For one sample, the light absorption of non-BC impurities in seasonal snow reached $56.89 \%$, which is the only time it exceeded BC light absorption. Biomass burning and fossil fuel are likely the major emission sources during the winter in Lanzhou, unlike the case over northeast China. These results are consistent with those of Wang et al. (2013), who found that snow particle light absorption was dominated by $\mathrm{BC}$ in northeast China in 2010.

Finally, we investigate atmospheric BC mass concentrations and their relative light absorption measured by the TSI spectrophotometer in Lanzhou during 5-25 August 2015. During this experiment, there were no noticeable trends of BC concentrations in Lanzhou. However, a notable feature in Fig. 9 is that the BC mass concentrations at night are generally much higher than during the day (Table 3 ). The unique topography of Lanzhou likely plays an important role in this phenomenon. Lanzhou is situated in a valley basin with low rainfall, high evaporation, low wind speeds, and a high calmwind frequency, which often leads to a thick inversion layer in which air pollutants accumulate during the night. The light absorption due to $\mathrm{BC}$ in the atmosphere ranges from $62.76 \%$ to $91.84 \%$, with a mean of $75.43 \%$.

\section{Conclusions}

We developed an improved two-sphere integration (TSI) spectrophotometer to quantify BC concentrations in snow and atmospheric samples over northern China. The TSI technique significantly reduces scattering effects caused by insoluble impurities deposited on filters. Therefore, the system more accurately measures light absorption due to $\mathrm{BC}$ and non-BC impurities. A system calibration using theoretical calculations for standard fullerene soot revealed that the TSI system can be used to assess BC concentrations with low uncertainty. A laboratory comparison revealed that the thermal-optical method can lead to a significant underestimate $(35 \%-45 \%)$ of $\mathrm{BC}$ concentrations for small-diameter particles $(\sim 50 \mathrm{~nm})$ due to the low filtration efficiency of $1 \mu \mathrm{m}$ quartz-fiber filters.

To further assess the accuracy of the improved TSI system, two field campaigns were carried out to collect seasonal snow and atmospheric samples during January-February 2014 and 5-25 August 2015 across northern China, respectively. Although the $\mathrm{BC}$ concentrations measured by the TSI and thermal-optical methods are well correlated for both the snow and atmospheric samples, we find that some $\mathrm{BC}$ values in seasonal snow measured by the two-step thermaloptical method were significantly overestimated compared with those measured by the TSI technique, by a factor of 1.57. Overall, the improved TSI optical system developed here is applicable to quantifications of $\mathrm{BC}$ concentrations in the atmosphere and snow-ice.

The spatial distribution of $\mathrm{BC}$ concentrations in seasonal snow over northern China during January-February 2014 ranged from 60 to $3800 \mathrm{ng} \mathrm{g}^{-1}$, with a mean value of $700 \mathrm{ng} \mathrm{g}^{-1}$, and ranged from 0.78 to $7.75 \mu \mathrm{g} \mathrm{m}^{-3}$ in the atmosphere during 5-25 August 2015 in Lanzhou. The spatial distribution of BC concentrations shows that large BC values are found mainly in the center of industrial regions near the central part, whereas lower values are found in northeast China. Light absorption is dominated by BC ( $\sim 40 \%$ to $90 \%$ ) in seasonal snow over northeast China, and this plays a dominant role in accelerating snowmelt. Atmospheric samples collected in Lanzhou show significant changes in BC concentrations between day and night. Frequent, stable atmospheric boundary layers at night during summer, caused by the valley-basin topography of Lanzhou, are largely responsible for air pollutant accumulation during the night.

Data availability. The data and code used in this paper are available upon request from the corresponding author (wxin@lzu.edu.cn). The data used for analysis are also available via a Zenodo archive, which can be found in the references (https://doi.org/10.5281/zenodo.3597866; Wang et al., 2020). 
Author contributions. The conceptualization and methodology were done by XW. The experiments were designed by XZ and WD. The formal analysis, investigation, writing of the original draft, and editing were performed by XW.

Competing interests. The authors declare that they have no conflict of interest.

Acknowledgements. We thank Thomas C. Grenfell and Qiang Fu from the University of Washington for providing the standard filters.

Financial support. This research has been supported by the National Key R\&D Program of China and the National Natural Science Foundation of China (grant nos. 2019YFA0606801 and 41775144, 41675065, and 41875091).

Review statement. This paper was edited by Mingjin Tang and reviewed by two anonymous referees.

\section{References}

Andreae, M. O. and Gelencsér, A.: Black carbon or brown carbon? The nature of light-absorbing carbonaceous aerosols, Atmos. Chem. Phys., 6, 3131-3148, https://doi.org/10.5194/acp-63131-2006, 2006.

Ban-Weiss, G. A., Cao, L., Bala, G., and Caldeira, K.: Dependence of climate forcing and response on the altitude of black carbon aerosols, Clim. Dynam., 38, 897-911, https://doi.org/10.1007/s00382-011-1052-y, 2012.

Ballach, J., Hitzenberger, R., Schultz, E., and Jaeschke, W.: Development of an improved optical transmission technique for black carbon (BC) analysis, Atmos. Environ., 35, 2089-2100, https://doi.org/10.1016/S1352-2310(00)00499-4, 2001.

Baumgardner, D., Kok, G., and Raga, G.: Warming of the Arctic lower stratosphere by light absorbing particles, Geophys. Res. Lett., 31, L06117, https://doi.org/10.1029/2003GL018883, 2004.

Baumgardner, D., Popovicheva, O., Allan, J., Bernardoni, V., Cao, J., Cavalli, F., Cozic, J., Diapouli, E., Eleftheriadis, K., Genberg, P. J., Gonzalez, C., Gysel, M., John, A., Kirchstetter, T. W., Kuhlbusch, T. A. J., Laborde, M., Lack, D., Müller, T., Niessner, R., Petzold, A., Piazzalunga, A., Putaud, J. P., Schwarz, J., Sheridan, P., Subramanian, R., Swietlicki, E., Valli, G., Vecchi, R., and Viana, M.: Soot reference materials for instrument calibration and intercomparisons: a workshop summary with recommendations, Atmos. Meas. Tech., 5, 1869-1887, https://doi.org/10.5194/amt-5-1869-2012, 2012.

Birch, M. E. and Cary, R. A.: Elemental carbon-based method for monitoring occupational exposures to particulate diesel exhaust, Aerosol Sci. Technol., 25, 221-241, https://doi.org/10.1080/02786829608965393, 1996.

Bond, T. C., Bussemer, M., Wehner, B., Keller, S., Charlson, R. J., and Heintzenberg, J.: Light absorption by primary particle emis- sions from a lignite burning plant, Environ. Sci. Technol., 33, 3887-3891, https://doi.org/10.1021/es9810538, 1999.

Bond, T. C., Doherty, S. J., Fahey, D. W., Forster, P. M., Berntsen, T., DeAngelo, B. J., Flanner, M. G., Ghan, S., Karcher, B., Koch, D., Kinne, S., Kondo, Y., Quinn, P. K., Sarofim, M. C., Schultz, M. G., Schulz, M., Venkataraman, C., Zhang, H., Zhang, S., Bellouin, N., Guttikunda, S. K., Hopke, P. K., Jacobson, M. Z., Kaiser, J. W., Klimont, Z., Lohmann, U., Schwarz, J. P., Shindell, D., Storelvmo, T., Warren, S. G., and Zender, C. S.: Bounding the role of black carbon in the climate system: A scientific assessment, J. Geophys. Res.-Atmos., 118, 5380-5552, https://doi.org/10.1002/jgrd.50171, 2013.

Cachier, H. and Pertuisot, M. H.: Particulate Carbon in Arctic Ice, Analusis, 22, M34-M37, 1994.

Cachier, H., Bremond, M. P., and Buat-Menard, P.: Determination of atmospheric soot carbon with a simple thermal method, Tellus B, 41, 379-390, https://doi.org/10.1111/j.16000889.1989.tb00316.x , 1989.

Cao, J. J., Lee, S. C., Chow, J. C., Watson, J. G., Ho, K. F., Zhang, R. J., Jin, Z. D., Shen, Z. X., Chen, G. C., Kang, Y. M., Zou, S. C., Zhang, L. Z., Qi, S. H., Dai, M. H., Cheng, Y., and $\mathrm{Hu}, \mathrm{K}$. : Spatial and seasonal distributions of carbonaceous aerosols over China, J. Geophys. Res.-Atmos., 112, D22S11, https://doi.org/10.1029/2006JD008205, 2007.

Carmagnola, C. M., Domine, F., Dumont, M., Wright, P., Strellis, B., Bergin, M., Dibb, J., Picard, G., Libois, Q., Arnaud, L., and Morin, S.: Snow spectral albedo at Summit, Greenland: measurements and numerical simulations based on physical and chemical properties of the snowpack, The Cryosphere, 7, 1139-1160, https://doi.org/10.5194/tc-7-1139-2013, 2013.

Chen, L. W. A., Chow, J. C., Watson, J. G., Moosmuller, H., and Arnott, W. P.: Modeling reflectance and transmittance of quartzfiber filter samples containing elemental carbon particles: Implications for thermal/optical analysis, J. Aerosol Sci., 35, 765-780, https://doi.org/10.1016/j.jaerosci.2003.12.005, 2004.

Chow, J. C., Watson, J. G., Pritchett, L. C., Pierson, W. R., Frazier, C. A., and Purcell, R. G.: The Dri Thermal Optical Reflectance Carbon Analysis System - Description, Evaluation and Applications in United-States Air-Quality Studies, Atmos. Environ., 27, 1185-1201, https://doi.org/10.1016/0960-1686(93)90245-T, 1993.

Chow, J. C., Watson, J. G., Crow, D., Lowenthal, D. H., and Merrifield, T.: Comparison of IMPROVE and NIOSH carbon measurements, Aerosol Sci. Technol., 34, 23-34, https://doi.org/10.1080/02786820119073, 2001.

Chow, J. C., Watson, J. G., Chen, L. W. A., Arnott, W. P., Moosmuller, H., and Fung, K.: Equivalence of elemental carbon by thermal/optical reflectance and transmittance with different temperature protocols, Environ. Sci. Technol., 38, 4414-4422, https://doi.org/10.1021/es034936u, 2004.

Chuang, C. C., Penner, J. E., Prospero, J. M., Grant, K. E., Rau, G. H., and Kawamoto, K.: Cloud susceptibility and the first aerosol indirect forcing: Sensitivity to black carbon and aerosol concentrations, J. Geophys. Res.-Atmos., 107, 4564, https://doi.org/10.1029/2000JD000215, 2002.

Chylek, P., Srivastava, V., Cahenzli, L., Pinnick, R. G., Dod, R. L., Novakov, T., Cook, T. L., and Hinds, B. D.: Aerosol and Graphitic Carbon Content of Snow, J. Geophys. Res.-Atmos., 92, 9801-9809, https://doi.org/10.1029/JD092iD08p09801, 1987. 
Clarke, A. D., Noone, K. J., Heintzenberg, J., Warren, S. G., and Covert, D. S.: Aerosol Light-Absorption Measurement Techniques - Analysis and Intercomparisons, Atmos. Environ., 21, 1455-1465, https://doi.org/10.1016/0004-6981(67)90093-5, 1967.

Cong, Z., Kang, S., Kawamura, K., Liu, B., Wan, X., Wang, Z., Gao, S., and Fu, P.: Carbonaceous aerosols on the south edge of the Tibetan Plateau: concentrations, seasonality and sources, Atmos. Chem. Phys., 15, 1573-1584, https://doi.org/10.5194/acp15-1573-2015, 2015.

Cross, E. S., Onasch, T. B., Ahern, A., Wrobel, W., Slowik, J. G., Olfert, J., Lack, D. A., Massoli, P., Cappa, C. D., Schwarz, J. P., Spackman, J. R., Fahey, D. W., Sedlacek, A., Trimborn, A., Jayne, J. T., Freedman, A., Williams, L. R., Ng, N. L., Mazzoleni, C., Dubey, M., Brem, B., Kok, G., Subramanian, R., Freitag, S., Clarke, A., Thornhill, D., Marr, L. C., Kolb, C. E., Worsnop, D. R., and Davidovits, P.: Soot Particle Studies-Instrument InterComparison-Project Overview, Aerosol Sci. Technol., 44, 592611,2010

Dang, C. and Hegg, D. A.: Quantifying light absorption by organic carbon in Western North American snow by serial chemical extractions, J. Geophys. Res.-Atmos., 119, 10247-10261, https://doi.org/10.1002/2014JD022156, 2014.

Doherty, S. J., Warren, S. G., Grenfell, T. C., Clarke, A. D., and Brandt, R. E.: Light-absorbing impurities in Arctic snow, Atmos. Chem. Phys., 10, 11647-11680, https://doi.org/10.5194/acp-1011647-2010, 2010.

Doherty, S. J., Dang, C., Hegg, D. A., Zhang, R. D., and Warren, S. G.: Black carbon and other light-absorbing particles in snow of central North America, J. Geophys. Res.-Atmos., 119, 1280712831, https://doi.org/10.1002/2014JD022350, 2014.

Fischer, K.: Bestimmung der Absorption von sichtbarer Strahlung durch Aerosolpartikeln, Contr. Atmos. Phys., 43, 244-254, 1970.

Flanner, M. G., Liu, X., Zhou, C., Penner, J. E., and Jiao, C.: Enhanced solar energy absorption by internally-mixed black carbon in snow grains, Atmos. Chem. Phys., 12, 4699-4721, https://doi.org/10.5194/acp-12-4699-2012, 2012.

Grenfell, T. C., Doherty, S. J., Clarke, A. D., and Warren, S. G.: Light absorption from particulate impurities in snow and ice determined by spectrophotometric analysis of filters, Appl. Optics, 50, 2037-2048, https://doi.org/10.1364/AO.50.002037, 2011.

Hadley, O. L. and Kirchstetter, T. W.: Black-carbon reduction of snow albedo, Nat. Clim. Change, 2, 437-440, https://doi.org/10.1038/NCLIMATE1433, 2012.

Hadley, O. L., Corrigan, C. E., Kirchstetter, T. W., Cliff, S. S., and Ramanathan, V.: Measured black carbon deposition on the Sierra Nevada snow pack and implication for snow pack retreat, Atmos. Chem. Phys., 10, 7505-7513, https://doi.org/10.5194/acp10-7505-2010, 2010.

Hansen, A. D. A., Rosen, H., and Novakov, T.: The aethalometer - An instrument for the real-time measurement of optical absorption by aerosol particles, Sci. Total Environ., 36, 191-196, https://doi.org/10.1016/0048-9697(84)90265-1, 1984.

Hansen, J., Sato, M., Ruedy, R., Nazarenko, L., Lacis, A., Schmidt, G.A., Russell, G., Aleinov, I., Bauer, M., Bauer, S., Bell, N., Cairns, B., Canuto, V., Chandler, M., Cheng, Y., Del Genio, A., Faluvegi, G., Fleming, E., Friend, A., Hall, T., Jackman, C., Kelley, M., Kiang, N., Koch, D., Lean, J., Lerner, J., Lo, K., Menon, S., Miller, R., Minnis, P., Novakov, T., Oinas, V., Perlwitz, J.,
Perlwitz, J., Rind, D., Romanou, A., Shindell, D., Stone, P., Sun, S., Tausnev, N., Thresher, D., Wielicki, B., Wong, T., Yao, M., and Zhang, S.: Efficacy of climate forcings, J. Geophys. Res.Atmos., 110, D18104, https://doi.org/10.1029/2005JD005776, 2005 .

Heintzenberg, J.: Fine particles in the global troposphere A review, Tellus B, 41, 149-160, https://doi.org/10.1111/j.16000889.1989.tb00132.x, 1989.

Hitzenberger, R.: Absorption-Measurements with an Integrating Plate Photometer Calibration and Error Analysis, Aerosol Sci. Technol., 18, 70-84, https://doi.org/10.1080/02786829308959585, 1993.

Horvath, H.: Comparison of Measurements of Aerosol OpticalAbsorption by Filter Collection and a Transmissometric Method, Atmos. Environ., 27, 319-325, https://doi.org/10.1016/09601686(93)90105-8, 1993a.

Horvath, H.: Atmospheric Light-Absorption - a Review, Atmos. Environ., 27, 293-317, https://doi.org/10.1016/09601686(93)90104-7, 1993b.

Huang, J. P., Fu, Q. A., Zhang, W., Wang, X., Zhang, R. D., Ye, H., and Warren, S. G.: Dust and Black Carbon in Seasonal Snow across Northern China, B. Am. Meteorol. Soc., 92, 175-181, https://doi.org/10.1175/2010BAMS3064.1, 2011.

IPCC: Climate Change 2013: The Physical Science Basis [M], edited by: Stocker, T. F., Qin, D., Plattner, G. K., Tignor, M., Allen, S. K., Boschung, J., Nauels, A., Xia, Y., Bex, V., and Midgley, P. M., Cambridge, United Kingdom and New York, NY, USA, 2013.

Ivleva, N. P., McKeon, U., Niessner, R., and Pöschl, U.: Raman microspectroscopic analysis of size-resolved atmospheric aerosol particle samples collected with an ELPI: Soot, humic-like substances, and inorganic compounds, Aerosol Sci. Technol., 41, 655-671, https://doi.org/10.1080/02786820701376391, 2007.

Jacobson, M. Z.: Global direct radiative forcing due to multicomponent anthropogenic and natural aerosols, J. Geophys. Res.-Atmos., 106, 1551-1568, https://doi.org/10.1029/2000JD900514, 2001.

Jenk, T. M., Szidat, S., Schwikowski, M., Gäggeler, H. W., Brütsch, S., Wacker, L., Synal, H.-A., and Saurer, M.: Radiocarbon analysis in an Alpine ice core: record of anthropogenic and biogenic contributions to carbonaceous aerosols in the past (1650-1940), Atmos. Chem. Phys., 6, 5381-5390, https://doi.org/10.5194/acp6-5381-2006, 2006.

Jimenez, J. L., Canagaratna, M. R., Donahue, N. M., Prevot, A. S. H., Zhang, Q., Kroll, J. H., DeCarlo, P. F., Allan, J. D., Coe, H., Ng, N. L., Aiken, A.C., Docherty, K. S., Ulbrich, I. M., Grieshop, A. P., Robinson, A. L., Duplissy, J., Smith, J. D., Wilson, K. R., Lanz, V. A., Hueglin, C., Sun, Y. L., Tian, J., Laaksonen, A., Raatikainen, T., Rautiainen, J., Vaattovaara, P., Ehn, M., Kulmala, M., Tomlinson, J. M., Collins, D. R., Cubison, M. J., Dunlea, E. J., Huffman, J. A., Onasch, T. B., Alfarra, M. R., Williams, P.I ., Bower, K., Kondo, Y., Schneider, J., Drewnick, F., Borrmann, S., Weimer, S., Demerjian, K., Salcedo, D., Cottrell, L., Griffin, R., Takami, A., Miyoshi, T., Hatakeyama, S., Shimono, A., Sun, J. Y., Zhang, Y. M., Dzepina, K., Kimmel, J. R., Sueper, D., Jayne, J. T., Herndon, S. C., Trimborn, A. M., Williams, L. R., Wood, E. C., Middlebrook, A. M., Kolb, C. E., Baltensperger, U., and Worsnop, D. R.: Evolution of organic aerosols in the atmosphere, Science, 326, 1525-1529, 2009. 
Koch, D., Schulz, M., Kinne, S., McNaughton, C., Spackman, J. R., Balkanski, Y., Bauer, S., Berntsen, T., Bond, T. C., Boucher, O., Chin, M., Clarke, A., De Luca, N., Dentener, F., Diehl, T., Dubovik, O., Easter, R., Fahey, D. W., Feichter, J., Fillmore, D., Freitag, S., Ghan, S., Ginoux, P., Gong, S., Horowitz, L., Iversen, T., Kirkevåg, A., Klimont, Z., Kondo, Y., Krol, M., Liu, X., Miller, R., Montanaro, V., Moteki, N., Myhre, G., Penner, J. E., Perlwitz, J., Pitari, G., Reddy, S., Sahu, L., Sakamoto, H., Schuster, G., Schwarz, J. P., Seland, Ø., Stier, P., Takegawa, N., Takemura, T., Textor, C., van Aardenne, J. A., and Zhao, Y.: Evaluation of black carbon estimations in global aerosol models, Atmos. Chem. Phys., 9, 9001-9026, https://doi.org/10.5194/acp-99001-2009, 2009.

Legrand, M., Preunkert, S., Schock, M., Cerqueira, M., Kasper-Giebl, A., Afonso, J., Pio, C., Gelencser, A., and Dombrowski-Etchevers, I.: Major 20th century changes of carbonaceous aerosol components (EC, WinOC, DOC, HULIS, carboxylic acids, and cellulose) derived from Alpine ice cores, J. Geophys. Res.-Atmos., 112, D23S11, https://doi.org/10.1029/2006JD008080, 2007.

Li, W., Shao, L., Zhang, D., Ro, C.-U., Hu, M., Bi, X., Geng, H., Matsuki, A., Niu, H., and Chen, J.: A review of single aerosol particle studies in the atmosphere of East Asia: morphology, mixing state, source, and heterogeneous reactions, J. Clean Prod., 112, 1330-1349, https://doi.org/10.1016/j.jclepro.2015.04.050, 2016.

Lim, S., Faïn, X., Zanatta, M., Cozic, J., Jaffrezo, J.-L., Ginot, P., and Laj, P.: Refractory black carbon mass concentrations in snow and ice: method evaluation and inter-comparison with elemental carbon measurement, Atmos. Meas. Tech., 7, 3307-3324, https://doi.org/10.5194/amt-7-3307-2014, 2014.

McMeeking, G. R., Morgan, W. T., Flynn, M., Highwood, E. J., Turnbull, K., Haywood, J., and Coe, H.: Black carbon aerosol mixing state, organic aerosols and aerosol optical properties over the United Kingdom, Atmos. Chem. Phys., 11, 9037-9052, https://doi.org/10.5194/acp-11-9037-2011, 2011.

Menon, S., Hansen, J., Nazarenko, L., and Luo, Y. F.: Climate effects of black carbon aerosols in China and India, Science 297, 2250-2253, https://doi.org/10.1126/science.1075159, 2002.

Ming, J., Xiao, C. D., Cachier, H., Qin, D. H., Qin, X., Li, Z. Q., and $\mathrm{Pu}$, J. C.: Black Carbon (BC) in the snow of glaciers in west China and its potential effects on albedos, Atmos. Res., 92, 114123, https://doi.org/10.1016/j.atmosres.2008.09.007, 2009.

Ming, J., Xiao, C. D., Sun, J. Y., Kang, S. C., and Bonasoni, P.: Carbonaceous particles in the atmosphere and precipitation of the Nam Co region, central Tibet, J. Environ. Sci., 22, 17481756, https://doi.org/10.1016/S1001-0742(09)60315-6, 2010.

Moosmuller, H., Chakrabarty, R. K., and Arnott, W. P.: Aerosol light absorption and its measurement: A review, J. Quant. Spectrosc. Ra., 110, 844-878, https://doi.org/10.1016/j.jqsrt.2009.02.035, 2009.

Moteki, N., Kondo, Y., Takegawa, N., and Nakamura, S.I.: Directional dependence of thermal emission from nonspherical carbon particles, J. Aerosol Sci., 40, 790-801, https://doi.org/10.1016/j.jaerosci.2009.05.003, 2009.

Ogren, J. A. and Charlson, R. J.: Elemental carbon in the atmosphere-cycle and lifetime, Tellus B, 35, 241-254, 1983.

Painter, T. H., Seidel, F. C., Bryant, A. C., Skiles, S. M., and Rittger, K.: Imaging spectroscopy of albedo and radiative forcing by light-absorbing impurities in mountain snow, J. Geophys. Res.Atmos., 118, 9511-9523, https://doi.org/10.1002/jgrd.50520, 2013.

Pan, Y. P., Wang, Y. S., Xin, J. Y., Tang, G. Q., Song, T., Wang, Y. H., Li, X. R., and Wu, F. K.: Study on dissolved organic carbon in precipitation in Northern China, Atmos. Environ., 44, 23502357, https://doi.org/10.1016/j.atmosenv.2010.03.033, 2010.

Pavese, G., Calvello, M., and Esposito, F.: Black Carbon and Organic Components in the Atmosphere of Southern Italy: Comparing Emissions from Different Sources and Production Processes of Carbonaceous Particles, Aerosol Air Qual. Res., 12, 11461156, https://doi.org/10.4209/aaqr.2011.12.0236, 2012.

Pedersen, C. A., Gallet, J. C., Strom, J., Gerland, S., Hudson, S. R., Forsstrom, S., Isaksson, E., and Berntsen, T. K.: In situ observations of black carbon in snow and the corresponding spectral surface albedo reduction, J. Geophys. Res.-Atmos., 120, 14761489, https://doi.org/10.1002/2014jd022407, 2015.

Petzold, A., Kopp, C., and Niessner, R.: The dependence of the specific attenuation cross-section on black carbon mass fraction and particle size, Atmos. Environ., 31, 661-672, https://doi.org/10.1016/S1352-2310(96)00245-2, 1997.

Petzold, A., Ogren, J. A., Fiebig, M., Laj, P., Li, S.-M., Baltensperger, U., Holzer-Popp, T., Kinne, S., Pappalardo, G., Sugimoto, N., Wehrli, C., Wiedensohler, A., and Zhang, X.-Y.: Recommendations for reporting "black carbon" measurements, Atmos. Chem. Phys., 13, 8365-8379, https://doi.org/10.5194/acp13-8365-2013, 2013.

Qian, Y., Wang, H., Zhang, R., Flanner, M. G., and Rasch, P. J.: A sensitivity study on modeling black carbon in snow and its radiative forcing over the Arctic and Northern China, Environ. Res. Lett., 9, 064001, https://doi.org/10.1088/1748-9326/9/6/064001, 2014.

Ramanathan, V. and Carmichael, G.: Global and regional climate changes due to black carbon, Nat. Geosci., 1, 221-227, https://doi.org/10.1038/Ngeo156, 2008.

Rosenfeld, D., Lohmann, U., Raga, G. B., O’Dowd, C. D., Kulmala, M., Fuzzi, S., Reissell, A., and Andreae, M. O.: Flood or drought: How do aerosols affect precipitation?, Science, 321, 1309-1313, https://doi.org/10.1126/science.1160606, 2008.

Schwarz, J. P., Doherty, S. J., Li, F., Ruggiero, S. T., Tanner, C. E., Perring, A. E., Gao, R. S., and Fahey, D. W.: Assessing Single Particle Soot Photometer and Integrating Sphere/Integrating Sandwich Spectrophotometer measurement techniques for quantifying black carbon concentration in snow, Atmos. Meas. Tech., 5, 2581-2592, https://doi.org/10.5194/amt-5-2581-2012, 2012.

Sharma, S., Brook, J. R., Cachier, H., Chow, J., Gaudenzi, A., and Lu, G.: Light absorption and thermal measurements of black carbon in different regions of Canada, J. Geophys. Res.-Atmos., 107, 4771, https://doi.org/10.1029/2002JD002496, 2002.

Slater, J. F., Currie, L .A., Dibb, J. E., and Benner, B. A.: Distinguishing the relative contribution of fossil fuel and biomass combustion aerosols deposited at Summit, Greenland through isotopic and molecular characterization of insoluble carbon, Atmos. Environ., 36, 4463-4477, https://doi.org/10.1016/S13522310(02)00402-8, 2002.

Spencer, M. T., Shields, L. G., and Prather, K. A.: Simultaneous measurement of the effective density and chemical composition of ambient aerosol particles, Environ. Sci. Technol., 41, 13031309, https://doi.org/10.1021/es061425+, 2007. 
Thevenon, F., Anselmetti, F. S., Bernasconi, S. M., and Schwikowski, M.: Mineral dust and elemental black carbon records from an Alpine ice core (Colle Gnifetti glacier) over the last millennium, J. Geophys. Res.-Atmos., 114, D17102, https://doi.org/10.1029/2008JD011490, 2009.

von Schneidemesser, E., Schauer, J. J., Hagler, G. S. W., and Bergin, M. H.: Concentrations and sources of carbonaceous aerosol in the atmosphere of Summit, Greenland, Atmos. Environ., 43, 41554162, https://doi.org/10.1016/j.atmosenv.2009.05.043, 2009.

Wang, M., Xu, B., Zhao, H., Cao, J., Joswiak, D., Wu, G., and Lin, S.: The Influence of Dust on Quantitative Measurements of Black Carbon in Ice and Snow when Using a Thermal Optical Method, Aerosol Sci. Technol., 46, 60-69, https://doi.org/10.1080/02786826.2011.605815, 2012.

Wang, X., Doherty, S. J., and Huang, J. P.: Black carbon and other light-absorbing impurities in snow across Northern China, J. Geophys. Res.-Atmos., 118, 1471-1492, https://doi.org/10.1029/2012JD018291, 2013.

Wang, X., Pu, W., Ren, Y., Zhang, X., Zhang, X., Shi, J., Jin, H., Dai, M., and Chen, Q.: Observations and model simulations of snow albedo reduction in seasonal snow due to insoluble light-absorbing particles during 2014 Chinese survey, Atmos. Chem. Phys., 17, 2279-2296, https://doi.org/10.5194/acp17-2279-2017, 2017.

Wang, X., Zhang, X., and Di, W.: Development of an improved two-sphere integration technique for quantifying black carbon concentrations in the atmosphere and seasonal snow [Data set], Atmos. Meas. Tech. Zenodo, https://doi.org/10.5281/zenodo.3597866, 2020.

Watson, J. G. and Chow, J. C.: Comparison and evaluation of in situ and filter carbon measurements at the Fresno Supersite, J. Geophys. Res.-Atmos., 107, 8341, https://doi.org/10.1029/2001jd000573, 2002.

Wolff, E. W. and Cachier, H.: Concentrations and seasonal cycle of black carbon in aerosol at a coastal Antarctic station, J. Geophys. Res.-Atmos., 103, 11033-11041, https://doi.org/10.1029/97JD01363, 1998.

$\mathrm{Xu}$, B. Q., Yao, T. D., Liu, X. Q., and Wang, N. L.: Elemental and organic carbon measurements with a twostep heating-gas chromatography system in snow samples from the Tibetan Plateau, Ann. Glaciol., 43, 257-262, https://doi.org/10.3189/172756406781812122, 2006.

Xu, B. Q., Cao, J. J., Hansen, J., Yao, T. D., Joswia, D. R., Wang, N. L., Wu, G. J., Wang, M., Zhao, H. B., Yang, W., Liu, X. Q., and He, J. Q.: Black soot and the survival of Tibetan glaciers, P. Natl. Acad. Sci. USA, 106, 22114-22118, https://doi.org/10.1073/pnas.0910444106, 2009a.
Xu, B. Q., Wang, M., Joswiak, D. R., Cao, J. J., Yao, T. D., Wu, G. J., Yang, W., and Zhao, H. B.: Deposition of anthropogenic aerosols in a southeastern Tibetan glacier, J. Geophys. Res.Atmos., 114, D17209, https://doi.org/10.1029/2008JD011510, 2009 b.

Xu, B. Q., Cao, J. J., Joswiak, D. R., Liu, X. Q., Zhao, H. B., and He, J. Q.: Post-depositional enrichment of black soot in snowpack and accelerated melting of Tibetan glaciers, Environ. Res. Lett., 7, 014022, https://doi.org/10.1088/1748-9326/7/1/014022, 2012.

Yang, H. and Yu, J. Z.: Uncertainties in charring correction in the analysis of elemental and organic carbon in atmospheric particles by thermal/optical methods, Environ. Sci. Technol., 36, 51995204, https://doi.org/10.1021/es025672z, 2002.

Yasunari, T. J., Tan, Q., Lau, K. M., Bonasoni, P., Marinoni, A., Laj, P., Menegoz, M., Takemura, T., and Chin, M.: Estimated range of black carbon dry deposition and the related snow albedo reduction over Himalayan glaciers during dry pre-monsoon periods, Atmos. Environ., 78, 259-267, https://doi.org/10.1016/j.atmosenv.2012.03.031, 2013.

Ye, H., Zhang, R. D., Shi, J. S., Huang, J. P., Warren, S. G., and $\mathrm{Fu}, \mathrm{Q}$.: Black carbon in seasonal snow across northern Xinjiang in northwestern China, Environ. Res. Lett., 7, 044002, https://doi.org/10.1088/1748-9326/7/4/044002, 2012.

Zhang, R. J., Ho, K. F., Cao, J. J., Han, Z. W., Zhang, M. G., Cheng, Y., and Lee, S. C.: Organic carbon and elemental carbon associated with PM10 in Beijing during spring time, J. Hazard. Mater., 172, 970-977, https://doi.org/10.1016/j.jhazmat.2009.07.087, 2009.

Zhao, C., Hu, Z., Qian, Y., Ruby Leung, L., Huang, J., Huang, M., Jin, J., Flanner, M. G., Zhang, R., Wang, H., Yan, H., Lu, Z., and Streets, D. G.: Simulating black carbon and dust and their radiative forcing in seasonal snow: a case study over North China with field campaign measurements, Atmos. Chem. Phys., 14, 1147511491, https://doi.org/10.5194/acp-14-11475-2014, 2014.

Zhou, Y., Wang, X., Wu, X. Q., Cong, Z. Y., Wu, G. M., and Ji, M. X.: Quantifying Light Absorption of Iron Oxides and Carbonaceous Aerosol in Seasonal Snow across Northern China, Atmosphere-Basel, 8, 63, https://doi.org/10.3390/atmos8040063, 2017. 